\title{
A novel variant of osteogenesis imperfecta type IV and low serum phosphorus level caused by a Val94Asp mutation in COL1AI
}

\author{
QI YANG $^{1 *}$, HONG XU $^{2 *}$, JINSI LUO $^{1}$, QINLE ZHANG ${ }^{1}$, BOBO XIE $^{1}$, SHENG YI $^{1}$, XIULIANG RONG $^{1}$, \\ JIN WANG ${ }^{1}$, ZAILONG QIN ${ }^{1}$, TINGTING JIANG ${ }^{1}$, LI LIN ${ }^{1}$, YANGJIN ZUO ${ }^{1}$ and XIN FAN ${ }^{1}$ \\ ${ }^{1}$ Genetic and Metabolic Central Laboratory, Guangxi Maternal and Child Health Hospital; \\ ${ }^{2}$ Nanning Region Center for Disease Prevention and Control, Nanning, Guangxi 530023, P.R. China
}

Received June 21, 2017; Accepted November 22, 2017

DOI: $10.3892 / \mathrm{mmr} .2018 .8436$

\begin{abstract}
Osteogenesis imperfecta (OI) is a rare congenital disorder characterized by bone fragility and fractures, and associated with bone deformity, short stature, dentin, ligament and blue-gray eye sclera. OI is caused by a heterozygous mutation in collagen $\alpha-1(\mathrm{I})$ chain (COL1A1) or collagen $\alpha-2$ (I) chain (COL1A2) genes that encode $\alpha$ chains of type I collagen. Collagen $\alpha$ chain peptide contains an $\mathrm{N}$-propeptide, which has a role in assembly and processing of collagen. Point mutations in the $\mathrm{N}$-propeptide domain appear to trigger OI. In the present study, a novel heterozygous missense mutation, c.281T>A (p.Val94Asp), was identified in the von Willebrand $\mathrm{C}$ domain of $\mathrm{N}$-terminal of type I collagen in an individual with type IV OI. The majority of N-terminal mutations are associated with OI/Ehlers-Danlos syndrome (EDS); however, in the present study, the affected individual did not suffer from EDS and the level of serum phosphorus of the patient was low $(0.67 \mathrm{mmol} / \mathrm{l})$. A number of clinical phenotypes were observed at the same variation site or in the same region on the polypeptide chain of COL1A, which suggests that additional genetic and environmental factors may influence the severity of OI. The present study may provide insight into the phenotype-genotype association in collagen-associated diseases and improve clinical diagnosis of OI.
\end{abstract}

\section{Introduction}

Osteogenesis imperfecta (OI) (types MIM 166200, 166210, 259420 and 166220), or brittle bone disease, is a rare connective tissue disorder characterized by increased bone fragility, low bone mass, short stature and other connective tissue

Correspondence to: Mrs. Xin Fan, Genetic and Metabolic Central Laboratory, Guangxi Maternal and Child Health Hospital, 59 Xiangzhu Road, Nanning, Guangxi 530023, P.R. China E-mail: fanxin602@163.com

*Contributed equally

Key words: osteogenesis imperfecta type IV, COL1Al gene, mutation, serum phosphorus manifestations. Extra-skeletal features manifest to a variable degree, including muscle weakness, brittle teeth, bluish-gray sclera and hearing defects. The traditional classification is based on clinical manifestations and radiographic criteria. The hereditary patterns of OI were classified into four primary types (I-IV) with either autosomal-dominant or autosomal-recessive patterns of inheritance, exhibiting variable levels of clinical severity (1). Their phenotypic presentation varies from mild to lethal and the prevalence of OI is $\sim 1 / 15,000$ globally and $0.04 \%$ in China $(2,3)$, among which half of the affected individuals are OI type I or IV while type IV has a broad phenotypic range overlapping types I and III (4).

Several factors have been reported to have a role in the severity of OI, including the location of the mutation on the polypeptide chain and the particular amino acid substitution (5). Over $90 \%$ of patients with OI exhibit heterozygous mutations in collagen $\alpha-1(\mathrm{I})$ chain (COL1A1) or collagen $\alpha-2(\mathrm{I})$ chain (COL1A2), genes encoding two type I pro-collagen $\alpha$ chains, pro- $\alpha 1(\mathrm{I})$ and pro- $\alpha 2(\mathrm{I})$. Translated collagen $\alpha$ chains include Nand C-terminals and a core triple helical domain of the Gly-X-Y triplet repeat unit. The $\mathrm{C}$-terminus is involved in the reorganization and assembly of type I collagen. N-terminal cleavage results in the formation of the $\alpha-1$ (I) chain which is terminated by a $\mathrm{N}$-telopeptide $(6,7)$. All $\mathrm{N}$-termini adhere to the surface of the fibrils preventing further accretion and limiting fibril diameter (8). Previous studies demonstrated that environmental factors also contribute to the severity of OI. Maternal smoking during pregnancy is associated with childhood bone fractures in offspring and diet is associated with the severity of OI $(9,10)$. COL1Al and COL1A2 are $\sim 18 \mathrm{~kb}$ and $38 \mathrm{~kb}$ long, respectively and are located in $17 \mathrm{q} 21.3-17 \mathrm{q} 22,7 \mathrm{q} 21.3-7 \mathrm{q} 22.3$, respectively, both with $>50$ exons. To date, $>1,000$ different COL1A1/COL1A2 mutations have been identified in patients with OI (11). The present study reports a Chinese patient with OI type IV disease, who carried a novel missense mutation c.281T>A in the $\mathrm{N}$-propeptide of collagen type I $\alpha$ chain in the COL1A1 gene. The present study may improve the disease-causing mutation database of collagen genes to improve the diagnosis of OI type IV.

\section{Materials and methods}

Patients. A 6-year-old boy was admitted to the GuangxiZhuang Autonomous Region Women and Children Care Hospital in 
August 2014 for genetic counseling of constitutional bone disease. According to the description of proband's mother, this patient previously suffered three fractures in each limb. Consequently, he was diagnosed with OI type IV following careful physical examination, capturing of radiologic images and genetic diagnosis. The patient's pedigree chart is presented in Fig. 1. From January 2015-December 2016, 300 normal Han individuals (1:1 sex ratio) aged 1-60 years were recruited. All participants agreed to carry out a genetic analysis and singed written informed consent for the study approved by the Genetic and Metabolic Central Laboratory of Guangxi Zhuang Autonomous Region Women and Children Care Hospital (Nanning, China).

Genetic analysis. A peripheral blood sample $(5 \mathrm{ml})$ was obtained from the patient, patient's parents and brother, and 300 normal controls. Genomic DNA was extracted from peripheral blood using Lab-Aid DNA kit (Zeesan Biotech Co., Ltd., Xiamen, China). DNA concentration was determined using NanoDrop ND-2000 spectrophotometer and software (NanoDrop 2000; NanoDrop Technologies; Thermo Fisher Scientific, Inc., Waltham, MA, USA). Polymerase chain reaction (PCR) primers were designed using an online tool Primer version 3 (frodo.wi.mit.edu) to include all exons and exon-intron boundaries of COL1A1 and COL1A2 genes (Tables II and III). Polymerase chain reaction was conducted in a $50 \mu 1$ reaction volume consisting of: $10 \mathrm{X}$ buffer, $1.5 \mathrm{mmol} / \mathrm{l}$ magnesium chloride, $200 \mu \mathrm{mol} / 1 \mathrm{dNTPs}, 400 \mathrm{nmol} / 1$ of each primer, $200 \mathrm{ng} / \mu \mathrm{l}$ DNA and 2 U Taq DNA polymerase (Takara Biotechnology Co., Ltd., Dalian, China). Initial denaturation occurred for $5 \mathrm{~min}$ at $95^{\circ} \mathrm{C}$, followed by 30 cycles of $30 \mathrm{sec}$ at $95^{\circ} \mathrm{C}, 30 \mathrm{sec}$ at $60^{\circ} \mathrm{C}$ and $60 \mathrm{sec}$ at $72^{\circ} \mathrm{C}$. Final extension occurred for $7 \mathrm{~min}$ at $72^{\circ} \mathrm{C}$. PCR products were stained with ethidium bromide and visualized on a UV transilluminator following $1.5 \%$ agarose gel electrophoresis and were sequenced directly in an ABI 3130 genetic analyzer (Thermo Fisher Scientific, Inc.). When a potential novel mutation was considered following alignment of the patient's genome sequence against the ClinVar (www.ncbi.nlm.nih.gov), HGMD (www.hgmd.cf.ac.uk/ac/), HPSD (liweilab.genetics.ac.cn/HPSD/), the SNP (www.ncbi. nlm.nih.gov/SNP) databases and osteogenesis imperfecta and Ehlers-Danlos syndrome variant databases (11), direct sequencing of the amplified PCR products from the same region of the 300 unaffected patients was performed to verify the possibility of the difference being caused by a polymorphism. Sorting Intolerant From Intolerant (12), PolyPhen 2.0 (13) and Mutation Taster (14) tools were used to evaluate the pathology of the novel mutations. Three-dimensional structures of wild type (WT) and mutant COL1A1 were predicted using I-TASSER (15) by importing WT and mutant COL1AI amino acid sequences. Subsequently, DNAMAN version 8.0 was used to perform multiple sequence alignment of novel mutations of OCA2 protein from different species.

\section{Results}

Patient description. The patient diagnosed with OI was a 6-year-old boy of Han ethnicity from the Guangxi province in China. The proband began walking at the age of 16 months and suffered three bone fractures. The first fracture occurred

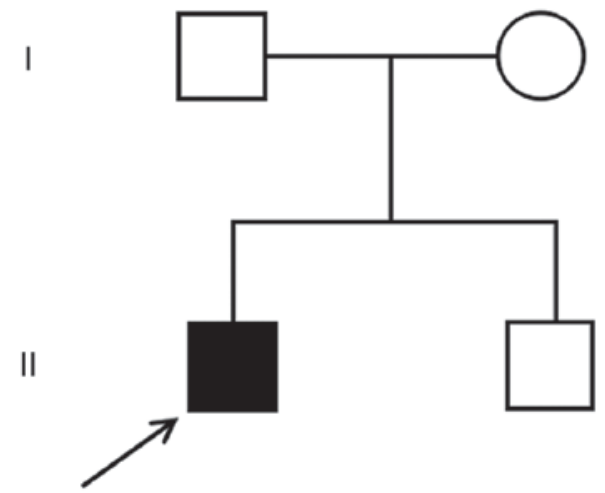

Figure 1. Pedigree chart of the family of the OI type IV patient. The black symbol indicates the patient with OI and white symbols represent unaffected individuals in the family. OI, osteogenesis imperfecta; L, left; R, right.

in the right tibia/fibula following a minor injury at 2 years of age. Subsequently, there have been two fractures, each caused by either a fall or collision. Physical examination revealed short stature. The boy was $98 \mathrm{~cm}$ tall and weighed $16 \mathrm{~kg}$, with distinct signs of dentinogenesis imperfecta, genu varum, deformities of mild scoliokyphosis and joint hypermobility. X-ray analysis demonstrated hip joint femoral head fractures, osteoporosis and multiple fractures of four limbs (Fig. 2). Biochemical examination demonstrated that his calcium level $(2.5 \mathrm{mmol} / \mathrm{l})$ was within normal range (2.25-2.75 $\mathrm{mmol} / \mathrm{l})$, whereas the level of serum phosphorus $(0.67 \mathrm{mmol} / \mathrm{l})$ was lower than normal serum phosphorus range $(1.29-1.94 \mathrm{mmol} / \mathrm{l})$.

Mutation analysis. Sequence analysis revealed no functional mutations in COL1A2 from the patient. However, a heterozygous mutation, c.281T >A (p.Va194Asp), was identified during sequence analysis of the COL1Al gene. This mutation was not identified in any other family members (brother, father and mother of the proband) or ethnically matched controls (Fig. 3). Notably, comparison with the osteogenesis imperfecta and Ehlers-Danlos syndrome variant databases, the Human Gene Mutation Database, HPSD and the SNP databases revealed that the mutation had not been previously identified. Functional predictions revealed that the novel missense variant may demonstrate deleterious effects by markedly altering the structure of the COL1Al protein. Multiple sequence alignments revealed that sequence conservation at residue 94 of pro- $\alpha 1$ (I) was poor in different organisms (Fig. 4).

Further protein structure prediction and analysis using I-TASSER revealed that the proportion of regions folding into an $\alpha$-helix and a $\beta$-sheet would increase and the proportion of random coils would decrease in mutant protein compared with the wild-type protein. Domains 1227-1230, 1266-1271, 1277-1279, 1390-1392, 1395-1398 and 1389-1400 were predicted to be altered from random coils into $\beta$-sheets, domains 3-5, 9 and 20-22 were predicted to be altered from random coils into $\alpha$-helices, domains 97-98 would form random coils instead of $\beta$-sheets, and domains 67-68 and 1259-1263 would fold into random coils instead of $\alpha$-helices. The overall fibril shape was predicted to be altered (Fig. 5). 
Table I. Comparison of OI types with COL1A1 mutations.

\begin{tabular}{|c|c|c|c|c|c|}
\hline Location & Mutation & Location & Outcome & OI type & (Refs.) \\
\hline 2 & c.111_117del & Deletion & Frameshift & OI IA & $(28)$ \\
\hline 2 & c. $141 \mathrm{C}>\mathrm{A}$ & Substitution & Nonsense & OI IA & (29) \\
\hline 2 & c. $174 \mathrm{C}>\mathrm{A}$ & Substitution & Nonsense & unknown & (11) \\
\hline 2 & c. $182 \mathrm{G}>\mathrm{T}$ & Substitution & Missense & OI I, OI III & $(29,30)$ \\
\hline 2 & c. $189 \mathrm{C}>\mathrm{A}$ & Substitution & Nonsense & unknown & (11) \\
\hline 2 & c.198_204dup & Duplication & Frameshift & OI I & (31) \\
\hline 2 & c. $199 \mathrm{~A}>\mathrm{T}$ & Substitution & Nonsense & OI I & (11) \\
\hline 2 & c.246delC & Deletion & Frameshift & OI I & (32) \\
\hline 2 & c. $266 \mathrm{G}>\mathrm{T}$ & Substitution & Missense & OI III, OI IV & (11) \\
\hline 2 & c.266_266delGinsCGCCGTCCCGGGGA & Insertion/Deletion & Frameshift & OI I & $(11)$ \\
\hline 2 & c.268_299-60del & Deletion & Other Site & OI I & $(30)$ \\
\hline 2 & c. $285 \mathrm{C}>\mathrm{A}$ & Substitution & Nonsense & OI I & $(11)$ \\
\hline $02 \mathrm{i}$ & c.299-5_313del & Deletion & Splice site & OI I & $(11)$ \\
\hline $02 \mathrm{i}$ & c. $299-1 \mathrm{G}>\mathrm{C}$ & Substitution & Splice site & OI I & $(11)$ \\
\hline
\end{tabular}

Adapted from the osteogenesis imperfecta and Ehlers-Danlos syndrome variant databases (11). OI, osteogenesis imperfecta; COL1A1, collagen $\alpha-1$ (I) chain. 2, 2nd exon of COL1A1; 02i, 2nd intron of COL1A1.

Table II. PCR primers and conditions used for mutation analysis of the COL1A1 gene.

\begin{tabular}{|c|c|c|c|c|}
\hline Exon & Forward $\left(5^{\prime}-3^{\prime}\right)$ & Reverse (5'-3') & $\begin{array}{l}\text { Product } \\
\text { size (bp) }\end{array}$ & $\begin{array}{l}\text { Annealing } \\
\text { temp }\left({ }^{\circ} \mathrm{C}\right)\end{array}$ \\
\hline 1 & GCTCTGATTGGCTGGGGCAC & CCCTTCCATTCCCGAGTCTCC & 445 & 60 \\
\hline 2 & CTGAGGTTGGAGTTGGAAGCC & GTTTCTTGGTCGGTGGGTG & 647 & 60 \\
\hline $3-5$ & GGGAGCAGCATTAGCAAACCT & GCAAAAGAGCCTGATGTTAGCA & 656 & 58 \\
\hline $6-7$ & GTCAGTTTCTTCCATCCTCAGT & AGTCCCTGTCAACCTTCTCC & 547 & 62 \\
\hline $8-9$ & TGGTAAGATTGGAGAAGGTTG & TTCCTCTGAGTATCGTTCCC & 437 & 58 \\
\hline $10-12$ & TAGGCGGTGGTGGGGAGGCA & TGGTGGGACTCTGGGGATGTG & 719 & 63 \\
\hline $13-16$ & CCACATCCCCAGAGTCCCAC & ATCAGAGACGGAGAACCCAGG & 808 & 64 \\
\hline $17-20$ & GAGAGGCAAGGTTGGGTTTC & GTTCCTGGGGGTGTGGCA & 802 & 60 \\
\hline $21-23$ & TGCCACACCCCCAGGAAC & AAGAGGAAGAAGATGCCCAGG & 428 & 60 \\
\hline $24-25$ & GGCATCTTCTTCСTCTTTTGGC & AAGTCTCAGGTGTGTTTGTCCC & 640 & 60 \\
\hline $26-29$ & TCTCACTTCAGCCCССТCAAC & GCGTCTAACCTCAATCCCTCT & 727 & 60 \\
\hline $30-32$ & CAGACCCCAGGAGGAAGGACC & GAGATTCAAAGCAGGCAGAGATG & 796 & 60 \\
\hline $33-35$ & GGAAACCCAGACACAAGCAGAAC & CCAGTCGGTGATGAAAAATGATG & 718 & 60 \\
\hline $36-38$ & CTGCCTCCATTACTGCTCСТСC & ACCTTTGCCGCCTTCTTTGCC & 709 & 62 \\
\hline $39-40$ & TGACAGCCCCTCCTATCCTC & CAAGTCCTGTGATGGTTTTTCTC & 450 & 60 \\
\hline $41-43$ & GGAGCCAAGGAGAACAGATTT & TCCGACACCCATCCCCAG & 661 & 60 \\
\hline $44-45$ & CTGGGAGTTGGGAGAGATGG & GAGGGGGAAACTGAGGCGAAG & 487 & 60 \\
\hline $46-47$ & CAGAGAGGGATTATGGGAGAGG & GAGGGAAGAGAGTGGGGATTAC & 774 & 60 \\
\hline $48-49$ & ССССТСАТССССТСТGСТСАТ & CCAGCTCTGTCCATCACCCTT & 800 & 60 \\
\hline $50-51$ & TAGCGGCTCACTCTTCCCTC & GTTTGGGTTGCTTGTCTGTTTC & 634 & 60 \\
\hline
\end{tabular}

PCR, polymerase chain reaction; bp, base pairs.

\section{Discussion}

Severity of OI mutation is determined by a number of genetic factors, including location, mutation type and mutated residues. Over 1,000 different COL1A1/COL1A2 mutations have been identified in patients with OI (11), accounting for $~ 90 \%$ of OI cases in patients with OI type I-IV. Additionally, there are a number of mutations identified in genes encoding proteins that interact with type I collagen, affecting the development of bones and leading to different symptoms of OI. These 

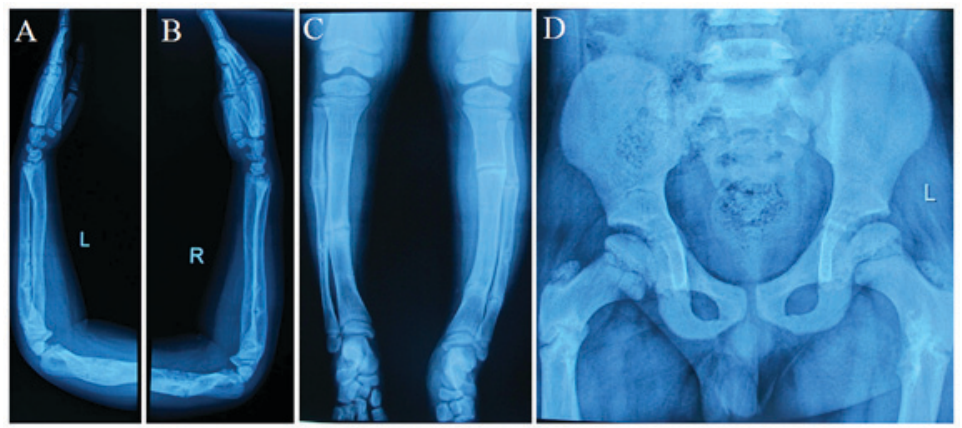

Figure 2. X-ray images from the patient with osteogenesis imperfecta type IV. X-ray images demonstrate the multiple fractures present in the (A) left upper limb, (B) right upper limb and (C) lower limbs. (D) Hip joint femoral head fractures and osteoporosis.

A

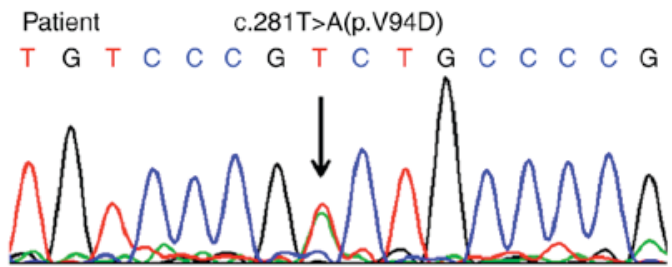

B

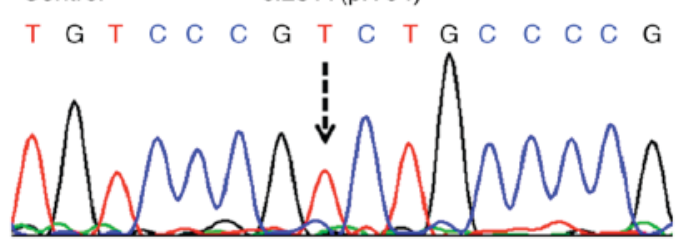

Figure 3. Sequence analysis of COL1A1 exon 2. The nucleotide sequence of (A) the patient and (B) a representative normal subject. The patient exhibits a novel heterozygous $\mathrm{T}>\mathrm{A}$ mutation at nucleotide 281 in exon 2 (c.281T>A), resulting in the substitution of valine with aspartic acid at codon 94 (p.V94D).

genes include, cartilage-associated protein (MIM no. 605497), P3H1 (MIM no. 610339), serpin peptidase inhibitor clade F member 1 (MIM no. 613329), peptidyl-prolyl cis-trans isomerase B (MIM no. 123841); and the non-collagen associated genes, peptidyl-prolyl cis-trans isomerase FKBP10 (MIM no. 607063), pigment epithelium-derived factor (MIM 172860) and proto-oncogene Wnt-1 (MIM no. 615220) (3,17-21).

Type I collagen, encoded by COL1A1 and COL1A2, consists of two pro- $\alpha 1$ chains and one pro- $\alpha 2$ chain, which interweave and form a dense structure. Each $\alpha$ chain contains three domains, one collagen triple helix repeat domain, one fibrillar collagen $\mathrm{C}$-terminal propeptide and $\mathrm{N}$-terminal propeptide. Collagens are generally extracellular structural proteins involved in formation of connective tissue structure. The sequence predominantly consists of repeats of the G-X-Y and polypeptide chains from triple helix motifs. The fibrillar C-terminal of collagen propeptide is the most conserved part of fibrillar collagens from invertebrates to vertebrates (22). The C-terminal propeptide, also termed the COLFI domain, has a role in tissue growth and repair by controlling intracellular assembly of procollagen molecules and extracellular assembly of collagen fibrils (23). The N-terminal propeptide is encoded by the first $\sim 200$ amino acids of collagen protein sequence and contains the von Willebrand $\mathrm{C}$ domain (vWFC) (24). The N-terminal amino acids of the $\alpha 1(\mathrm{I})$ chain

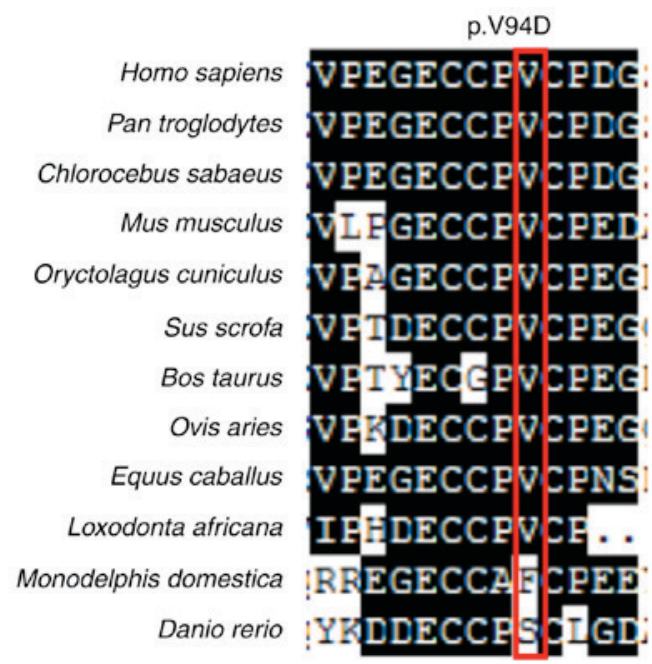

Figure 4. Multispecies alignment of COL1A1 sequence. The novel mutation site (p.V94D) is indicated with a red box. The black background indicates complete sequence conservation; the white background indicates sequence variation.

has a role of a stabilizing anchor for the amino end of a type I collagen triple helix (25). Furthermore, the von Willebrand C (vWFC) domain has a role in binding to and regulating other components, including bone morphogenetic proteins of the extracellular matrix during development (26).

In the present study, the patient with OI type IV exhibited a thymine to adenine substitution mutation at nucleotide c. 281 in the COL1A1 gene, resulting in p.Val94Asp missense substitution. This variant was not identified in patient's parents, his brother, or 300 controls. The identified mutation was located in the second exon of the COL1Al gene which is a part of the N-terminal propeptide domain of the pro- $\alpha-1(\mathrm{I})$ collagen chain (16). A previous study revealed that most N-terminal mutations are associated with OI/EDS (27) and appear to alter the structure of $\mathrm{N}$-anchor and conformation of the $\mathrm{N}$-propeptide cleavage site, resulting in the incorporation of partially processed procollagen with uncleaved N-propeptides into fibrils (25). During proteosynthesis, the $\mathrm{N}$-terminal propeptide is removed from the pro- $\alpha-1(\mathrm{I})$ chain by a specific proteinase to form the $\alpha-1(\mathrm{I})$ chain terminated by $\mathrm{N}$-telopeptide. In the present study, the patient did not have EDS, as the substitution identified in his genome was not localized in close proximity to the N-proteinase cleavage site; thus, its occurrence was not 
Table III. PCR primers and conditions used for mutation analysis of the COL1A2 gene.

\begin{tabular}{|c|c|c|c|c|}
\hline Exon & Forward (5'-3') & Reverse (5'-3') & $\begin{array}{l}\text { Product } \\
\text { size (bp) }\end{array}$ & $\begin{array}{c}\text { Annealing } \\
\text { temp }\end{array}$ \\
\hline 1 & GGTTTCGGCTAAGTTGGAGG & GGTGCCCTCCCATCTAACC & 248 & 60 \\
\hline 2 & TCCCTGCCATACTTTTGACCT & ATGTAACTTCTTCССТTCCAAGA & 282 & 60 \\
\hline 3 & TTCCAAAATAGGCGGGGCTA & TGCCTTCCATCTCCAGAATAAA & 738 & 62 \\
\hline 4 & GCTTCCAATCCTCCAGCTGA & ATTCGCTTCTTCTGCAGTGC & 399 & 60 \\
\hline 5 & TCTTAGGTTTCTACAGGGCCT & GCACACAAAGACCAGTCCTG & 356 & 58 \\
\hline 6 & AGTTAAGGCAGAGGAAGGGC & TGGCGTGGTAAAATGTGACA & 399 & 58 \\
\hline $7-10$ & CACAACAATGGCACTGCTAAG & GTTCTGTCAGGCATATTCAGCT & 548 & 60 \\
\hline $11-12$ & ACTTTGGAGGGAAGAAGTCAC & TGGAGGTCATGGGGAATTTCA & 768 & 60 \\
\hline $13-16$ & TCTGTGTGTCTGGCATAATTGA & АССТTСССТСТССТTCTGTC & 1,436 & 62 \\
\hline $17-19$ & CCAAGATGGCAGAATCAAGCA & AGGAAGGGCATGTCTGTGTG & 872 & 60 \\
\hline $20-23$ & AGCTTCTCTTTACCTTGACCCA & ACCTCATAGCCATTGTATCAAGT & 1,236 & 60 \\
\hline 24 & ACTCTTTTCACACTTCCCAGC & TCTCTTGCATCCCCTTGTCA & 462 & 62 \\
\hline $25-26$ & TCATCCGTGGCAGCATCATA & CCTGGGGATGCCATCTTGAA & 749 & 62 \\
\hline $27-29$ & ATTTGGGCTTTCGTGGGAAC & GGCTCATTCTCTCCATCAGC & 895 & 60 \\
\hline 30 & TGCACTCATGTAGATACTGCCA & AGAGACTTGTTGCAGGGTCA & 267 & 60 \\
\hline 31 & TAAATGCAAACCAGGGCTCG & TCCACTGGAATCGGATTGCT & 364 & 60 \\
\hline 32 & TAGCCCAGCCTTCTTTGTGT & GCATGGTTGACAGCTGTTCA & 561 & 60 \\
\hline 33 & CTGCAGCCCATTGTGATGTT & TAGAGGTCCCGGCTTCCTAA & 742 & 60 \\
\hline 34 & ATCCAACCAGAGTGCAGTGA & GCGCAACATGGAGAGACTTT & 429 & 60 \\
\hline $35-38$ & AGCCCCGTGTCCATCTAAAA & CAGGCAGAAGAAGGGGCATA & 1,404 & 63 \\
\hline 39 & GCСТАССТССТАСТССТTGG & GGGGACTGGTGTTCACATGA & 403 & 60 \\
\hline 40 & ACCAGTGGCATGACATTGTT & TACTTAAACTGGGGAGGCGG & 1,010 & 60 \\
\hline 41 & TGCCAAGATGTAAACTCACCG & TGCAGAGGAGTAAACGCAAT & 565 & 60 \\
\hline 42 & TGAATGACACGAGGCTCACT & ATACTTGGGCCCAGTTTTGC & 562 & 60 \\
\hline $43-46$ & AGCTACAACATAGGGGCTGG & CAAGAGTGAGATGGAGTTAGCC & 1,136 & 60 \\
\hline $47-49$ & TGCACTGCTGAAATAGGTTGT & GAAATGAGGTTGGGTGCTGG & 1,247 & 60 \\
\hline 50 & TTTTCATGGAGGAGGGGAGG & CCCAGGAAAGGAACAGGTCT & 497 & 60 \\
\hline 51 & AGATGACCTTGCCTCAGTCT & AGGCCACTGAAGTCTCAAGA & 812 & 60 \\
\hline 52 & СССТСССАСТАAАGACACCC & TGTGCAGAAGAAATGGAAGGA & 434 & 60 \\
\hline
\end{tabular}

PCR, polymerase chain reaction; bp, base pairs.
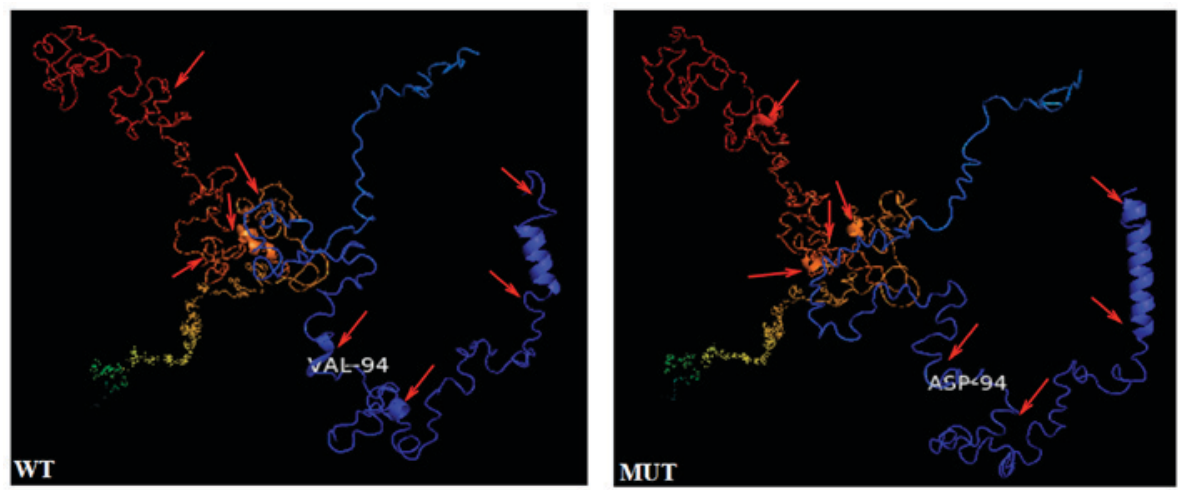

Figure 5. Three-dimensional structure estimation, indicating that in the variant protein there would be an increase in the proportion of $\alpha$-helix and $\beta$-sheet regions, and that the random coil regions would be decreased in the mutant protein compared to the wild-type protein. The dimer alterations are indicated by an arrow. WT, wild-type; MUT, mutant.

likely to prevent $\mathrm{N}$-propeptide removal. The mutation identified in the present study was predicted to lead to an increased number of $\alpha$-helices and $\beta$-sheets, disruption of integrity of the $\mathrm{N}$-terminal and delayed $\mathrm{N}$-propeptide removal, decreased fibril 
size and the phenotypic characteristics of OI. The substitution identified in the present study was also located in the vWF-c binding region (amino acid residues 38-96). The mutation was predicted to lead to delayed vWF-c binding and prevent normal regulation of components of the extracellular matrix during development. In addition to the symptoms of OI type IV, the patient also had low serum phosphorus levels $(0.67 \mathrm{mmol} / \mathrm{l})$, which may suggest an association between the vWF-c binding complex and regulation of serum phosphorus level. Further studies would be necessary to verify this hypothesis.

Similar mutations have been observed in the same region of the VWFC domain of N-terminal in the collagen type I $\alpha$ chain (Table I) in the majority of OI patients with mild symptoms. There are two splicing mutations, 5 non-sense mutations, 4 frameshift mutations, 1 site variation (c.268_299-60del) and 2 missense mutations. The majority of patients with these mutations presented with the same mild symptoms of OI type I (28-32). The phenotypes resulting from null variants are caused by haploinsufficiency (33). The other mutations causing OI changed the distinct activities of the N-propeptide of collagen I and its regulation of collagen fiber assembly and fibroblast function (34). Similar symptoms to those exhibited in the patient of the present study are also caused by the p.Val94Asp substitution, but to a milder degree. Patient with OI with missense mutations c. $182 \mathrm{G}>\mathrm{T}$ and c. $266 \mathrm{G}>\mathrm{T}$, were diagnosed with OI type I or OI type III and OI type III or OI type IV, respectively $(26,28)$. Smoking during pregnancy may affect the growth of fetus and lead to an increased risk of serious fractures in childhood (9). Furthermore, a study by Mertz et al (10) demonstrated that in heterozygous Colla2 $2^{\text {tm IMcbr/s }}$ (G610C) mice, a low protein diet had beneficial effects on osteoblast differentiation and bone matrix mineralization and it also affected bone modeling and suppressed overall animal growth. To a certain extent, the severity of OI is affected by environmental factors (10). Additionally, if the mutation occurs in a poorly conserved site, then the phenotype impact is relatively mild. The aforementioned findings of previous studies, combined with the description of the novel mutation c.281T >A described in the present study, suggest that the splicing, frameshift, nonsense and missense mutation pattern, the affected COLIAl region, additional genes and possibly other environmental factors including smoking and diet may influence the severity of OI.

In conclusion, a novel missense mutation c.281T >A, p.Val94Asp in exon 2 of COL1Al gene resulting in OI type IV and low serum phosphorus level was identified in a patient with sporadic OI. The novel missense mutation disrupted vWF-c binding and the integrity of the N-terminal of the collagen type I $\alpha$ chain. It remains to be elucidated how this substitution leads to the abnormal function of collagen I and low serum phosphorus levels. Detailed clinical features and molecular diagnostics have a role in expanding evidence of genetic and phenotypic heterogeneity and determining the phenotype-genotype associations in OI. The present study contributed to the understanding of COL1A1 mutations in the Han Chinese population with OI type IV.

\section{Acknowledgements}

The present study was supported by the Open Project Program of the Shanghai Key Laboratory of Birth Defect (grant no. 16DZKF1014), Children's Hospital of Fudan University and the project of science and technology of Guangxi Zhuang Autonomous Region (grant no. 14124004-1-8).

\section{References}

1. Sillence DO and Rimoin DL: Classification of osteogenesis imperfect. Lancet 8072: 1041-1042, 1978.

2. Ben Amor IM, Glorieux FH and Rauch F: Genotype-phenotype correlations in autosomal dominant osteogenesis imperfecta. J Osteoporos 2011: 540178, 2011.

3. Pyott SM, Tra TT, Leistritz DF, Pepin MG, Mendelsohn NJ, Temme RT, Fernandez BA, Elsayed SM, Elsobky E, Verma I, et al: WNT1 mutations in families affected by moderately severe and progressive recessive osteogenesis imperfecta. Am J Hum Genet 92: 590-597, 2013.

4. Sillence DO, Senn A and Danks DM: Genetic heterogeneity in osteogenesis imperfecta. J Med Genet 16: 101-116, 1979.

5. Byers PH, Wallis GA and Willing MC: Osteogenesis imperfecta: Translation of mutation to phenotype. J Med Genet 28: 433-442, 1991.

6. Forlino A, Cabral WA, Barnes AM and Marini JC: New perspectives on osteogenesis imperfecta. Nat Rev Endocrinol 7: 540-557, 2011.

7. Boot-Handford RP and Tuckwell DS: Fibrillar collagen: The key to vertebrate evolution? A tale of molecular incest. Bioessays 25: 142-151, 2003.

8. Birk DE: Type V and collagen: heterotypic type I/V collagen interactions in the regulation of fibril assembly. Micron 32: 223-237, 2001

9. Parviainen R, Auvinen J, Pokka T, Serlo W and Sinikumpu JJ: Maternal smoking during pregnancy is associated with childhood bone fractures in offspring-A birth-cohort study of 6718 children. Bone 101: 202-205, 2017.

10. Mertz EL, Makareeva E, Mirigian LS, Koon KY, Perosky JE, Kozloff KM and Leikin S: Makings of a brittle bone: Unexpected lessons from a low protein diet study of a mouse OI model. Matrix Biol 52-54: 29-42, 2016.

11. Dalgleish R: Osteogenesis imperfecta variant database. http://oi.gene.le.ac.uk; accessed July 20, 2015.

12. Kumar P, Henikoff S and Ng PC. Predicting the effects of coding non-synonymous variants on protein function using the SIFT algorithm. Nat Protoc 4: 1073-1081, 2009.

13. Adzhubei IA, Schmidt S, Peshkin L, Ramensky VE, Gerasimova A, Bork P, Kondrashov AS and Sunyaev SR: A method and server for predicting damaging missense mutations. Nat Methods 7: 248-249, 2010.

14. Schwarz JM, Cooper DN, Schuelke M and Seelow D. MutationTaster2: mutation prediction for the deep-sequencing age. Nat Methods 11: 361-362, 2014.

15. Zhang Y: I-TASSER server for protein 3D structure prediction. BMC Bioinformatics 9: 40, 2008.

16. Dalgleish R: The human type I collagen mutation database. Nucleic Acids Res 25: 181-187, 1997.

17. Cabral WA, Chang W, Barnes AM, Weis M, Scott MA, Leikin S, Makareeva E, Kuznetsova NV, Rosenbaum KN, Tifft CJ, et al: Prolyl 3-hydroxylase 1 deficiency causes a recessive metabolic bone disorder resembling lethal/severe osteogenesis imperfecta. Nat Genet 39: 359-365, 2007.

18. MorelloR, Bertin TK, Chen Y,Hicks J, Tonachini L, Monticone M, Castagnola P, Rauch F, Glorieux FH, Vranka J, et al: CRTAP is required for prolyl 3-hydroxylation and mutations cause recessive osteogenesis imperfecta. Cell 127: 291-304, 2006.

19. Alanay Y, Avaygan H, Camacho N, Utine GE, Boduroglu K, Aktas D, Alikasifoglu M, Tuncbilek E, Orhan D, Bakar FT, et al: Mutations in the gene encoding the RER protein FKBP65 cause autosomal-recessive osteogenesis imperfecta. Am J Hum Genet 86: 551-559, 2010.

20. van Dijk FS, Nesbitt IM, Zwikstra EH, Nikkels PG, Piersma SR, Fratantoni SA, Jimenez CR, Huizer M, Morsman AC, Cobben JM, et al: PPIB mutations cause severe osteogenesis imperfecta. Am J Hum Genet 85: 521-527, 2009.

21. Christiansen HE, Schwarze U, Pyott SM, AlSwaid A, Al Balwi M, Alrasheed S, Pepin MG, Weis MA, Eyre DR and Byers PH: Homozygosity for a missense mutation in SERPINH1, which encodes the collagen chaperone protein HSP47, results in severe recessive osteogenesis imperfecta. Am J Hum Genet 86: 389-398, 2010. 
22. Sicot FX, Exposito JY, Masselot M, Garrone R, Deutsch J and Gaill F: Cloning of an annelid fibrillar-collagen gene and phylogenetic analysis of vertebrate and invertebrate collagens. Eur J Biochem 246: 50-58, 1997.

23. Bourhis JM, Mariano N, Zhao Y, Harlos K, Exposito JY, Jones EY, Moali C, Aghajari N and Hulmes DJ: Structural basis of fibrillar collagen trimerization and related genetic disorders. Nat Struct Mol Biol 19: 1031-1036, 2012.

24. Stover DA and Verrelli BC: Comparative vertebrate evolutionary analyses of type I collagen: Potential of COLlalgene structure andintron variation for common bone-related diseases. Mol Biol Evol 28: 533-542, 2011.

25. Makareeva E, Cabral WA, Marini JC and Leikin S: Molecular mechanism of alpha 1(I)-osteogenesis imperfecta/Ehlers-Danlos syndrome: Unfolding of an $\mathrm{N}$-anchor domain at the $\mathrm{N}$-terminal end of the type I collagen triple helix. J Biol Chem 281: 6463-6470, 2006.

26. Sandell LJ, McAlinden A and Sandell KS: The vWFC domain of type IIA procollagen amino-propeptide functions as an antagonist of bonemorphogenetic proteins. J Musculoskelet Neuronal Interact 2: 521-523, 2002.

27. Cabral WA, Makareeva E, Colige A, Letocha AD, Ty JM, Yeowell HN, Pals G, Leikin S and Marini JC: Mutations near amino end of alpha1(I) collagen cause combined osteogenesis imperfecta/Ehlers-Danlos syndrome by interference with N-propeptide processing. J Biol Chem 280: 19259-19269, 2005.

28. Lindahl K, Åström E, Rubin CJ, Grigelioniene G, Malmgren B, Ljunggren Ö and Kindmark A: Genetic epidemiology, prevalence and genotype-phenotype correlations in the Swedish population with osteogenesis imperfecta. Eur J Hum Genet 23: 1042-1050, 2015.

29. Hruskova L, Fijalkowski I, Van Hul W, Marik I, Mortier G Martasek P and Mazura I: Eight mutations including 5 novel ones in the COL1A1 gene in Czech patients with osteogenesis imperfecta. Biomed Pap Med Fac Univ Palacky Olomouc Czech Repub 160: 442-447, 2016.
30. Zhang ZL, Zhang H, Ke YH, Yue H, Xiao WJ, Yu JB, Gu JM, $\mathrm{Hu}$ WW, Wang C, He JW and Fu WZ: The identification of novel mutations in COL1A1, COL1A2 and LEPRE1 genes in Chinese patients withosteogenesis imperfecta. J Bone Miner Metab 30: 69-77, 2012

31. Kaneto CM, Lima PS, Zanette DL, Prata KL, Pina Neto JM, de Paula FJ and Silva WA Jr: COL1A1 and miR-29b show lower expression levels during osteoblast differentiation of bone marrow stromal cells from Osteogenesis Imperfecta patients. BMC Med Genet 15: 45, 2014.

32. Hartikka H, Kuurila K, Körkkö J, Kaitila I, Grénman R, Pynnönen S, Hyland JC and Ala-Kokko L: Lack of correlation between the type of COL1A1 or COL1A2 mutation and hearing loss in osteogenesis imperfecta patients. Hum Mutat 24: 147-154, 2004.

33. Redford-Badwal DA, Stover ML, Valli M, McKinstry MB and Rowe DW: Nuclear retention of COL1A1 messenger RNA identifies null alleles causing mild osteogenesis imperfecta. J Clin Invest 97: 1035-1040, 1996

34. Rosset EM, Trombetta-eSilva J, Hepfer G, Yao H and Bradshaw AD: SPARC and the N-propeptide of collagen I influence fibroblast proliferation and collagen assemblyin the periodontal ligament. PLoS One 12: e0173209, 2017.

This work is licensed under a Creative Commons Attribution-NonCommercial-NoDerivatives 4.0 International (CC BY-NC-ND 4.0) License. 